\title{
Insilico Screening and Comparative Study on the Effectiveness of Textile Dye Decolourization by Crude Laccase Immobilised Alginate Encapsulated Beads from Pleurotus Ostreatus
}

\author{
Chinnathambi Velu ${ }^{1 *}$, Ezhilarasan Veeramani ${ }^{1}$, Sridhar Suntharam ${ }^{2}$, Kasinathan Kalimuthu ${ }^{1}$ \\ ${ }^{1}$ Research Associate, ARMATS BIOTEK Research Institute, Kottur, Chennai, India-600085
}

${ }^{2}$ Assistant Professor, Jeppiaar Engineering College, Jeppiaar nagar, Chennai, India-600119

\begin{abstract}
The necessity to safeguard the environment has increased the potential of enzyme usage in textile processing to ensure eco-friendly production. Laccase enzyme formulation has been used in textile processing such as biobleaching, dyeing, rove scouring, finishing, neps removal, printing, wash-off treatment, dye synthesis and effluent treatment. However, a high cost associated with biocatalyst production is still a hindrance to their use. Pleurotus ostreatus is a white-rot fungus that produces a ligninolytic enzyme complex rich in several laccase iso-enzymes. The main objective of this study is optimize influence of $\mathrm{pH}$ and stability of divalent metal ion-immobilzed crude laccase enzyme towards decolourization of prototype textile dyes such as Reactive red 80 (Red F3B) and Reactive blue 21(T Blue G). Wheat bran is used as a lead candidature for production of lignolytic enzyme using Pleurotus osteratus by solid state fermentation. Two divalent metal ions such as $\mathrm{Zn} 2^{+}$and $\mathrm{Ca}^{+}$were selected to study the influence of metal ions towards the dye decolourization. Results revealed that $\mathrm{Ca}^{+}$ion was better compared to $\mathrm{Zn2}{ }^{+}$ion towards enzyme immobilization and its influence on dye decolourization in the optimal pH 5.5. Finally, interactions between laccase and dyes were studied exclusively using Insilco structure based molecular docking methods.
\end{abstract}

Keywords: Dye degradation; Pleurotus ostreatus;Agricultural wastes; Laccase; Molecular docking

\section{Introduction}

Nearly ten thousand types of synthetic dyes are widely used in the textile, paper, printing and leather tanning industries, corresponding to $8 \times 10^{5}$ tonnes per year [1]. The chemical classes of synthetic dyes mostly used in industrial processes are azo, anthraquinone, sulfur, indigoid, triphenylmethyl (trityl) and phthalocyanine derivatives, although other types have many applications such as triazyne[2].Besides the color effect, the majority of these compounds are toxic, carcinogenic and highly persistent in the environment. Conventional biological treatment of wastewater is not effective for degradation of dyes, and so a number of chemical and physical techniques have been used to remove them, including adsorption to inorganic or organic matrices, decolorization by photo catalysis and oxidation [3].

However, some ligninolytic microorganisms are capable of degrading a wide variety of pollutants resembling lignin or its derivative, and are an attractive option due to low cost, specificity and the possibility of total mineralization of these compounds [4]. Basidiomycete's fungi are the most efficient lignin-degrading organisms that produce mainly laccase (EC 1.10.3.2), lignin peroxidase (EC 1.11.10.14) and manganese peroxidase (EC 1.11.1.13). Laccases are copper-containing oxidases biocatalyzes the oxidation of electron-rich natural and synthetic organic substrates, in a non-specific manner and degrade them into nontoxic molecular species without forming any recalcitrant metabolites. So only laccase are been used for bioremediation process due to their ability to degrade azo, heterocyclic, reactive and polymeric dyes [5].

A number of oxidative enzymes from bacteria, fungi and plants have been reported to play an important role in numerous waste treatment applications [6], Laccase is one of these oxidative enzymes, which appears to have a great potential [7] and it alone has a limited effect on bioremediation due to its specificity for phenolic subunits in lignin.

Value added bioproducts are at receiving end with greater demand in the global market. Potentially high titres of enzyme products can be produced by solid substrate fermentation [8]. Low cost alternative like agro-wastes are bio-prospected for enhanced enzyme production. Solid-state fermentation (SSF) is generally defined as a culture for the production of ligninolytic enzymes because it mimics the natural environment of the white rot fungi $[9,10]$. The inductive capability of rice bran to laccase production may be related with its phenolic compounds such as ferulic acid, vanillic acid which were reported to be an inducer for laccase production by white rot fungi $[11,12]$. Ferulic acid is found approximately $0.1 \%(\mathrm{w} / \mathrm{v})$ and easily prepared in large quantity from rice bran [13]. Wheat bran provides a conducive, natural habitat for high secretion of lingo-cellulolytic enzymes without incorporation any initial amount of carbon and nitrogen supplements, thereby reducing the process economics. Natural phenolic mediators such as ferulic acid, coumaric acid and syringic acid are present as abundant source in wheat bran, which stimulates in enhanced laccase enzyme production in white rot fungi [14].

Biological processes are efficient at low contaminant concentrations, can be sensitive to shock loads, require long hydraulic retention times and form large amounts of solid residues [15]. Some of these disadvantages can be overcome in an enzyme-based reactor, since enzymes are able to operate over a broad concentration range $[16,17]$. The potential advantages of this enzymatic treatment, as compared to

*Corresponding author: Chinnathambi Velu, Research Associate, ARMATS BIOTEK Research Institute, Kottur, Chennai, India-600085, E-mail: chinna.velu1@ gmail.com

Received July 29, 2011; Accepted November 19, 2011; Published November 21, 2011

Citation: Velu C, Veeramani E, Suntharam S, Kalimuthu K (2011) Insilico Screening and Comparative Study on the Effectiveness of Textile Dye Decolourization by Crude Laccase Immobilised Alginate Encapsulated Beads from Pleurotus Ostreatus. J Bioprocess Biotechniq 1:109 doi: 10.4172/2155-9821.1000109

Copyright: (c) 2011 Velu C, et al. This is an open-access article distributed unde the terms of the Creative Commons Attribution License, which permits unrestricted use, distribution, and reproduction in any medium, provided the original author and source are credited. 
Citation: Velu C, Veeramani E, Suntharam S, Kalimuthu K (2011) Insilico Screening and Comparative Study on the Effectiveness of Textile Dye Decolourization by Crude Laccase Immobilised Alginate Encapsulated Beads from Pleurotus Ostreatus. J Bioprocess Biotechniq 1:109 doi: $10.4172 / 2155-9821.1000109$

Page 2 of 6

conventional treatments, include application to recalcitrant materials, operation at high and low contaminant concentrations over a wide $\mathrm{pH}$, temperature and salinity range. Recent research in this area has focused on enzymatic process for the treatment of wastewater and soil $[18,19]$.

In general, it is accepted that in order to increase the potential use of enzymes in wastewater treatment processes, their immobilization is absolutely essential for biochemical stability and reuse [20-22]. Consequently, several studies support the immobilization of laccase. By using these immobilized forms, adequate characteristics including high resistance to thermal denaturation, significant improvement of the enzymatic activity, and its preservation for long periods, have been frequently reported.

In the present study, an attempt has been made to explore the potential decolourization of synthetic textile dyes by using immobilized laccase enzymes isolated from white rot fungus Pleurotus ostreatus and also in remediation of the dye. The results obtained from the decolourization of two reactive dyes by the fungus have been described in this article.

\section{Materials and Methods}

\section{Organism and inoculum}

The fungal culture, Pleurotus ostreatus, was obtained from the Microbiology Department, Thiyagarayar college of Arts and Science, Madurai, and was maintained in Potato Dextrose Agar medium (PDA), This was used as inoculums for the experiments.

\section{Chemicals}

The azo dye Reactive Red 80 (Red F3B) and Reactive Blue 21(T Blue G) Figure 1 and 2 were obtained from local dye manufacturing unit,

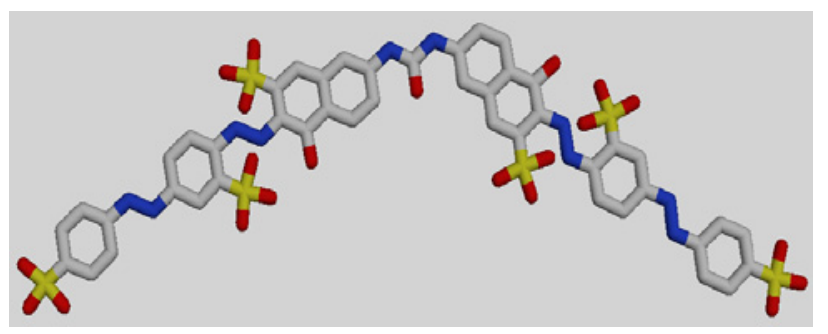

Figure 1: Reactive Red 80

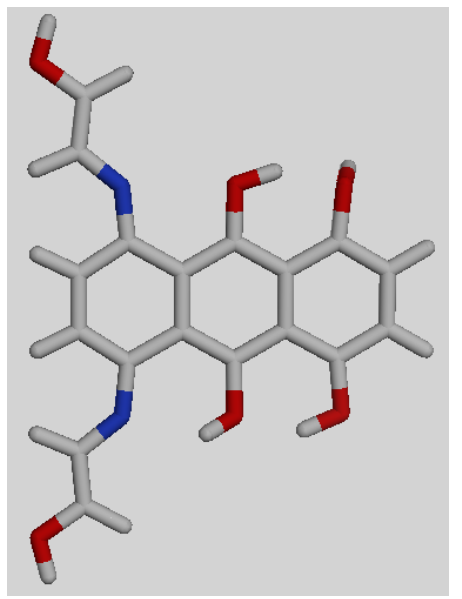

Figure 2: Reactive Blue 21
Tirupur, Tamil Nadu, India. The chemical structure of reactive dyes are shown in Figure 1, 2 were selected on the basis of their structural diversity and frequent use in local textile industries. The media components and chemicals were purchased from SD Fine Labs, Himedia Labs, and Bombay, India. All chemicals used were of analytical grade.

\section{Enzyme production}

Laccase enzyme was produced using solid state fermentation method. Totally, three different agro-wastes were used as substrates, namely wheat bran, rice bran and green gram. 20 grams of each agro waste was moistened $(70 \%)$ with double distilled water and transferred into the conical flasks $(250 \mathrm{ml})$ and sterilised. $6 \mathrm{~mm} 5$ discs of Pleurotus osteratus (5 day old culture) were inoculated and the flask incubated at room temperature for 12 days. The contents were extracted with $50 \mathrm{ml}$ sodium acetate buffer $(0.2 \mathrm{M})$ at $\mathrm{pH} 5.4$ and kept overnight in the shaker. The filtrate was centrifuged at $5000 \mathrm{rpm}$ for 20 minutes, the supernatant was collected and subjected to dialysis and stored at $4^{\circ} \mathrm{C}$. Later, the partially purified enzyme was used in enzyme estimation and dye degradation studies.

\section{Enzyme activity assay}

Extra cellular laccase activity was measured spectrophotometrically following Wolfenden and Wilson method [23] by utilizing syringaldazine as substrate for partially purified enzyme. The reaction mixture contains $0.1 \mathrm{ml}$ of $1 \mathrm{mM}$ syringaldazine in $1.8 \mathrm{ml}$ of $0.2 \mathrm{M}$ sodium acetate buffer ( $\mathrm{pH} 5.4$ ) and $0.1 \mathrm{ml}$ of enzyme. The reaction was monitored by measuring the change in $\mathrm{A}_{530}$ for 3 minutes. One unit enzyme activity was defined as the amount of enzyme that oxidizes $1 \mathrm{~m}$ mole of syringaldazine per minute at $25^{\circ} \mathrm{C}$. The experiment was carried out three times finally the mean value has taken as enzyme activity.

Unit $/ \mathrm{ml}=\frac{(\text { Final OD }- \text { Initial OD }) \times 1000 \times \text { total volume } \times \text { dilution factor }}{\text { Molecular enzyme coefficient } \times \text { enzyme volume } \times \text { time }}$

\section{pH stability of partially purified Laccase [10]}

For determination of $\mathrm{pH}$ stability of partially purified laccase enzyme from Pleurotus ostreatus, using wheat bran, the enzyme was incubated with different buffers of $\mathrm{pH}$ ranging from 4.0, 4.6, 5.0, 5.6, 6.0, $6.6,7.0,7.6$, and 8.0 after 60 mins incubation the samples were assayed for enzyme activity under standard condition as described before. The experiment was carried out three times; the mean value has been taken as $\mathrm{pH}$ stability.

\section{Temperature stability of partially purified Laccase [11]}

To determine the temperature stability of partially purified laccase enzyme from Pleurotus ostreatus using wheat bran, the enzyme was incubated with sodium acetate buffer of $\mathrm{pH} 5.8$ was incubated with different temperature ranging from $40^{\circ} \mathrm{C}, 50^{\circ} \mathrm{C}, 60^{\circ} \mathrm{C}, 700 \mathrm{C}, 80^{\circ} \mathrm{C}, 90^{\circ} \mathrm{C}$ and $100^{\circ} \mathrm{C}$ after $15 \mathrm{mins}$ incubation the samples were assayed for enzyme activity under standard condition as described before. The experiment was carried out three times; the mean value has been taken as $\mathrm{pH}$ stability.

\section{Enzyme activity on gel}

Gel electrophoresis was carried out on glass plates of $10.5 \times 10.5 \mathrm{~cm}$ (Biorad, USA) in 10\% (w/v) polyacrylamide gel with Tris/glycine buffer, $\mathrm{pH}$ 8.3. To detect laccase activity after NATIVE- PAGE, this gel was incubated at $35^{\circ} \mathrm{C}$ for $30 \mathrm{~min}$. It was then rinsed with sodium acetate buffer $0.2 \mathrm{M}$, pH 5.4 for $10 \mathrm{~min}$ and subsequently submerged in $0.1 \mathrm{ml}$ guaiacol. The laccase active band was highlighted in dark brown. 
Citation: Velu C, Veeramani E, Suntharam S, Kalimuthu K (2011) Insilico Screening and Comparative Study on the Effectiveness of Textile Dye Decolourization by Crude Laccase Immobilised Alginate Encapsulated Beads from Pleurotus Ostreatus. J Bioprocess Biotechniq 1:109 doi: 10.4172/2155-9821.1000109

Page 3 of 6

\section{Dye decolourization by enzyme immobilization technique}

Immobilization of laccase enzyme was carried out using two different metal ions (calcium and zinc). 3 grams of sodium alginate was added slowly to warm water which was continuously stirred. Later, 5-10 $\mathrm{ml}$ of the enzyme was added and mixed well. The enzyme beads were prepared at three different $\mathrm{pH}$ values of $4.5,5.5$ and 6.5 by adjusting the $\mathrm{pH}$ of the sodium alginate solution accordingly before adding the enzyme.

Calcium and zinc alginate beads formation:The dissolved sodium alginate solution was dropped from a height of 15- 20 centimetres into beak ers containing $0.2 \mathrm{M}$ calcium chloride solution. Each drop, falling into the beaker, settled in the form of beads and the enzyme was entrapped in the core region of each bead. The beads formed were kept in the calcium chloride solution for 3-4 hours at room temperature in order to harden. After 3 hours, the beads were washed with double distilled water and stored in $50 \mathrm{mM}$ calcium chloride solution, like wise prepared Zinc alginate beads by using zinc chloride solution instead of calcium chloride.

\section{Effective $\mathrm{pH}$ and metal ions optimization in dye degradation}

Two Reactive dyes were collected from textile units located in Tirupur, Tamil Nadu, India ie, Reactive Red 180 and Reactive Blue 21. The dyes were dissolved in double distilled water in the range of $100 \mathrm{ppm}$. Later, the prepared dyes were treated with the above mentioned enzyme beads (calcium alginate and zinc alginate).

The degradation of dyes was analyzed using a spectrophotometer. Reactive Red 180 was analyzed at $540 \mathrm{~nm}$ and Reactive Blue 21 at $630 \mathrm{~nm}$. The absorbance was measured every $24 \mathrm{hr}$ for eleven days. The degree of decolourization was calculated using the following formula.

decolourization percentage $=($ Initial absorbance - final absorbance $/$ initial absorbance) x 100

\section{Optimization of $\mathrm{pH}$ in dye decolourization with Czapek's dox broth medium}

The Czapek's dox [24] broth medium was prepared in $250 \mathrm{ml}$ conical flasks for each $100 \mathrm{ml}$ at 3 different $\mathrm{pH}$ values of $4.5,5.5$ and 6.5. The dyes (Reactive Red 180 and reactive Blue 21) were amended individually for each $\mathrm{pH}$ value. The medium was autoclaved and inoculated in 5 discs of Pleurotus ostreatus fungus. The absorbance of the dye in all the flasks was measured every $24 \mathrm{hr}$ for eleven days. The degree of decolourization was calculated using the following formula.

decolourization percentage $=($ Initial absorbance - final absorbance $/$ initial absorbance) x 100

\section{In silico analysis}

Homology modelling and structural analysis: The protein sequences used in this project were isolated from Universal Protein Resource [25] The templates used for homology modelling were obtained by running BLAST against the Protein Data Bank (PDB)[26]. On the basis of these hits given by BLAST, the required template PDB structures were downloaded from the protein data bank [27] and global alignment was then performed between the COX-2 sequence and the selected template. The identities between templates were retrieved in terms of the score provided by ClustalW [28]. The structure was modelled using effective and comparative molecular modelling software named MODELLER 27. Modelled structures were then validated with the help of DOPE scores [29] defined by MODELLER. Later, these structures were analyzed with the help of PROCHECK [30] all the macromolecules and ligands were viewed and analyzed with the help of two molecular viewers namely Chimera [31] and VMD [32].

Molecular docking studies: Molecular Docking is a computational technique used in Cheminformatics research. It involves the rapid Computational assessment of most favourable interacting regions between two different molecules. PyRx is virtual screening software for Computational Drug Discovery (CDD). It uses a large body of already established open source software such as Auto Dock 4 [33] and Auto Dock Vina. These two are used as docking software. Python was used as a programming/scripting language. Open Babel was used for importing SDF files, removing salts and energy minimization. Initially, dyes were energy minimized using the steepest decent method [34] with MMFF94 force field [35] later subjected to molecular docking analysis.

\section{Results and Discussion}

The main objective of this study was the application of laccase systems in dye decolourization. The activity of the laccase enzyme excreted by Pleurotus ostreatus was investigated through SSF on agro-industrial waste including wheat bran (WB), rice bran (RB) and green gram (GG). These wastes acted as the sole carbon source.

\section{Laccase enzyme assay using syringaldazine}

Wheat bran substrate showed the highest enzyme activity (2.565U/ $\mathrm{ml}$ ) after dialysis Chart 1, various types of oxidative enzymes are produced by white rot fungi in order to make use of lignocellulosic substrates for nutrition [36] SSF has been considered an efficient method for enzyme production in biotechnology due to its high yield.

The high level of laccase production could be attributed to the presence of ferulic acid in wheat bran. In this study, we selected SSF using various agro wastes such as wheat bran, rice bran and green gram for optimizing the best substrate that exhibits maximum laccase activity. The results indicated that after harvesting and dialysis, the maximum laccase activity was reported in the 12th day sample of wheat bran, whereas other samples showed declining activity.

\section{pH stability of partially purified Laccase}

Among the different $\mathrm{pH}$ values such as 4.0, 4.6, 5.0, 5.6, 6.0, 6.6, 7.0, 7.6, and 8.0 after 60 mins incubation the $\mathrm{pH} 6.0$ showed high activity Chart 2.

\section{Temperature stability of partially purified laccase}

Among the different temperature such as $400 \mathrm{C}, 500 \mathrm{C}, 600 \mathrm{C}, 700 \mathrm{C}$, $800 \mathrm{C}, 900 \mathrm{C}$ and $1000 \mathrm{C}$ after $60 \mathrm{mins}$ incubation the samples were assayed for enzyme activity under standard condition as described before. Laccase showed high stability at the temperature 700C so laccase is thermo stability in nature Chart 3.

\section{Zymogram analysis: laccase activity on native PAGE}

The activity of partially purified Laccase was determined on native PAGE using guaiacol as a substrate. The oxidized region appeared as a clear dark brown band Figure 3.

\section{Dye decolourization by Enzyme immobilization technique}

Effective $\mathrm{pH}$ and effective metal ion optimization in dye decolorizing process by enzyme immobilization technique:Laccase enzyme beads were prepared using two metal ions ie., calcium chloride and zinc chloride at three different $\mathrm{pH}$ levels (4.5, 5.5, and 6.5). Reactive Red 80 and Reactive Blue 21 were used for the analysis of degradation bye 
Citation: Velu C, Veeramani E, Suntharam S, Kalimuthu K (2011) Insilico Screening and Comparative Study on the Effectiveness of Textile Dye Decolourization by Crude Laccase Immobilised Alginate Encapsulated Beads from Pleurotus Ostreatus. J Bioprocess Biotechniq 1:109 doi: 10.4172/2155-9821.1000109

Page 4 of 6

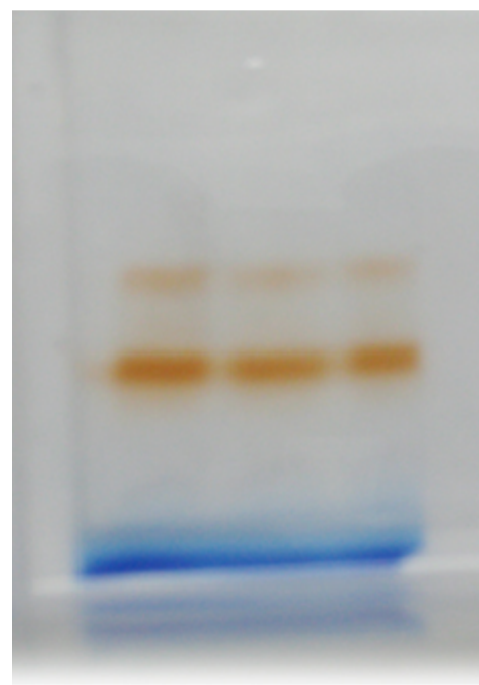

Figure 3: Laccase activity on Native page.

\begin{tabular}{|c|c|c|c|c|}
\hline $\mathrm{pH}$ & \multicolumn{2}{|c|}{ Reactive Red 80 at 540nm } & \multicolumn{2}{c|}{ Reactive Blue 21 at 630nm } \\
\hline & $\begin{array}{c}\text { Calcium alginate } \\
\text { Beads }\end{array}$ & $\begin{array}{c}\text { Zinc Alginate } \\
\text { Beads }\end{array}$ & $\begin{array}{c}\text { Calcium alginate } \\
\text { Beads }\end{array}$ & $\begin{array}{c}\text { Zinc Alginate } \\
\text { Beads }\end{array}$ \\
\hline 4.5 & 29.26 & 13.04 & 33.21 & 20.84 \\
\hline 5.5 & 40.71 & 19.99 & 67.42 & 24.71 \\
\hline 6.5 & 28.70 & 15.57 & 33.02 & 24.09 \\
\hline
\end{tabular}

Table 1: Effective $\mathrm{pH}$ and effective metal ion optimization in dye decolorizing process by enzyme immobilization technique.

\begin{tabular}{|l|l|l|l|l|l|l|l|}
\hline $\begin{array}{l}\text { Reactive Red } 80 \text { at } \\
540 \mathrm{~nm}\end{array}$ & \multicolumn{5}{|c|}{ Dye decolourization percentage for 11 days } \\
\hline S.no & pH & $\begin{array}{l}\text { On day } \\
1 \text { st }\end{array}$ & $\begin{array}{l}\text { On day } \\
\text { 3rd }\end{array}$ & $\begin{array}{l}\text { On day } \\
\text { 5th }\end{array}$ & $\begin{array}{l}\text { On day } \\
7 \text { th }\end{array}$ & $\begin{array}{l}\text { On day } \\
\text { 9th }\end{array}$ & $\begin{array}{l}\text { On day } \\
11 \text { th }\end{array}$ \\
\hline 1 & 4.5 & 6.69 & 11.87 & 19.08 & 23.02 & 33.34 & 45.65 \\
\hline 2 & 5.5 & 15.45 & 27.78 & 39.09 & 48.67 & 56.90 & 67.20 \\
\hline 3 & 6.5 & 11.23 & 19.78 & 24.67 & 31.56 & 40.89 & 49.61 \\
\hline
\end{tabular}

Table 2: $\mathrm{pH}$ optimization in dye decolorization with Czapek's dox broth medium for Reactive Red 80 at $540 \mathrm{~nm}$.

\begin{tabular}{|l|l|l|l|l|l|l|l|}
\hline \multicolumn{2}{|c|}{$\begin{array}{c}\text { Reactive Blue 21 } \\
\text { at 630nm }\end{array}$} & \multicolumn{5}{c|}{ Dye decolourization percentage for 11 days } \\
\hline S.no & pH & $\begin{array}{l}\text { On day } \\
1 \text { st }\end{array}$ & $\begin{array}{l}\text { On day } \\
\text { 3rd }\end{array}$ & $\begin{array}{l}\text { On day } \\
5 \text { th }\end{array}$ & $\begin{array}{l}\text { On day } \\
7 \text { th }\end{array}$ & $\begin{array}{l}\text { On day } \\
\text { 9th }\end{array}$ & $\begin{array}{l}\text { On day } \\
11 \text { th }\end{array}$ \\
\hline 1 & 4.5 & 18.03 & 23.35 & 29.23 & 35.45 & 41.66 & 57.83 \\
\hline 2 & 5.5 & 15.09 & 28.07 & 37.45 & 49.01 & 71.90 & 88.05 \\
\hline 3 & 6.5 & 11.21 & 17.56 & 24.65 & 29.37 & 30.48 & 51.65 \\
\hline
\end{tabular}

Table 3: $\mathrm{pH}$ optimization in dye decolorization with Czapek's dox broth medium for Reactive Blue 21 at $630 \mathrm{~nm}$.

\begin{tabular}{|l|l|l|l|l|l|l|}
\hline S.No & Dye & $\begin{array}{l}\text { Binding } \\
\text { Energy }\end{array}$ & $\begin{array}{l}\text { Ligand } \\
\text { Efficiency }\end{array}$ & $\begin{array}{l}\text { Ref } \\
\text { RMS }\end{array}$ & $\begin{array}{l}\text { Hydrogen } \\
\text { Bond }\end{array}$ & $\begin{array}{l}\text { Molecular } \\
\text { Weight } \\
\text { (daltons) }\end{array}$ \\
\hline 1 & $\begin{array}{l}\text { Reactive } \\
\text { Red 80 }\end{array}$ & -1.76 & -0.02 & 23.67 & VAL 218 & 381.37 \\
\hline 2 & $\begin{array}{l}\text { Reactive } \\
\text { Blue 21 }\end{array}$ & -4.74 & -0.18 & 25.16 & VAL 218 & 293.31 \\
\hline
\end{tabular}

Table 4: Docking analysis.

immobilised laccase. From the detailed analysis, the optimum metal ion for dye decolourization using immobilized system was found to be calcium at a $\mathrm{pH}$ of 5.5. The reactive dye Red 80 showed maximum dye degradation percentage at $\mathrm{pH} 5.5$ was 40.71 on $11^{\text {th }}$ day while other $\mathrm{pH}$ values showed dye degradation percentage for $\mathrm{pH} 4.5$ was $29.26 \%$ and 6.5 was $28.70 \%$ by using calcium alginate beads. And by using Zinc alginate beads, the dye degradation percentage was at $\mathrm{pH} 4.5=13.04 \%$, $5.5=19.99 \%$ and $6.5=15.57 \%$ on 11 th day. Whereas the reactive Blue 21 showed maximum dye degradation percentage at $\mathrm{pH} 5.5$ was $67.42 \%$ on $11^{\text {th }}$ day while other $\mathrm{pH}$ values showed dye degradation percentage for $\mathrm{pH} 4.5$ was $33.21 \%$ and 6.5 was $33.02 \%$ by using calcium alginate beads. And by using Zinc alginate beads, the dye degradation percentage was at $\mathrm{pH} 4.5=20.84 \%, 5.5=24.71 \%$ and $6.5=24.09 \%$ on $11^{\text {th }}$ day Table 1.

\section{pH optimization in dye decolourization with Czapek's dox broth medium}

The optimum $\mathrm{pH}$ for the maximum dye degradation was found to be 5.5 through Czapek's dox broth medium analysis Table 2 and 3 .

\section{Molecular modelling of laccase}

The sequence of Laccase was retrieved from Universal Protein Resource (UniProt) and its corresponding sequence id was P51589. It consists of 529 amino acids. This sequence was subjected to similarity search against Protein Data Bank, using the BLAST tool offered by NCBI. Later, the templates were selected on the basis of structural hits and its alignment pattern against the query sequence. The selected templates were as follows: chain A of $1 \mathrm{GYC}$, chain A of $3 \mathrm{KW} 7$ and chain A of to $1 \mathrm{~V} 10$.

The advanced modelling tutorial package offered in MODELLER was utilized for comparative molecular modelling. The DOPE score belonging to the best modeled structure was -60304.7734 . The stereo-

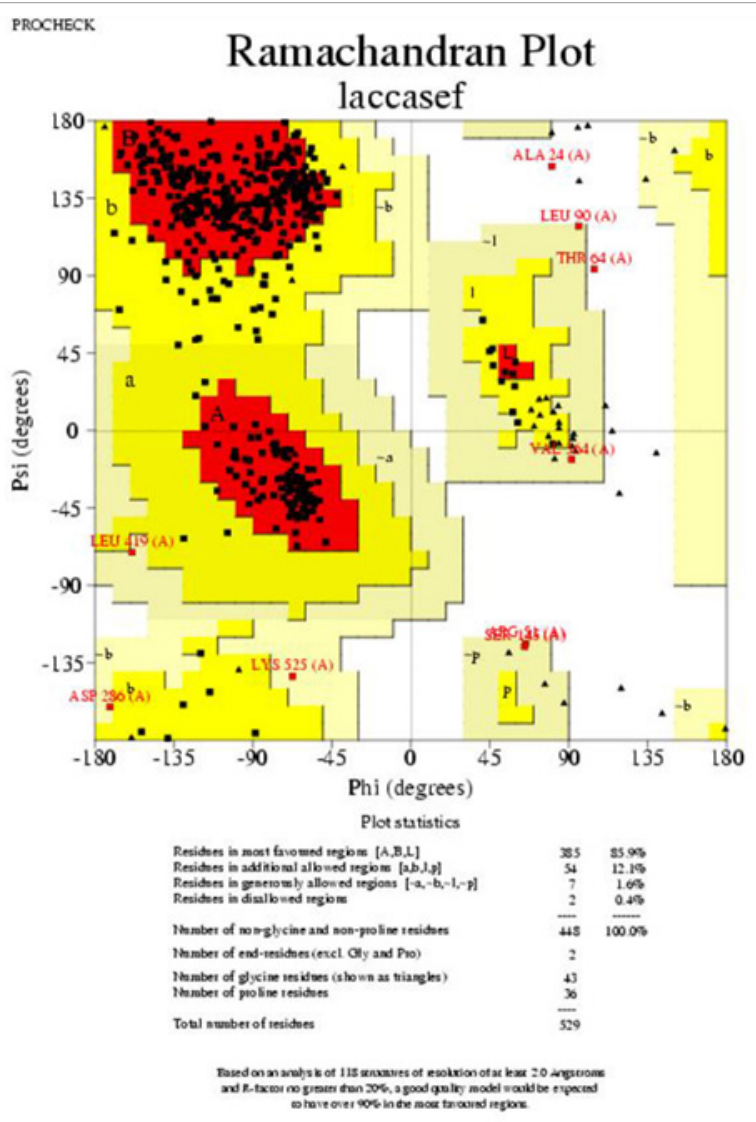

Figure 4: PROCHECK structure validation-plot. 
Citation: Velu C, Veeramani E, Suntharam S, Kalimuthu K (2011) Insilico Screening and Comparative Study on the Effectiveness of Textile Dye Decolourization by Crude Laccase Immobilised Alginate Encapsulated Beads from Pleurotus Ostreatus. J Bioprocess Biotechniq 1:109 doi: $10.4172 / 2155-9821.1000109$

Page 5 of 6

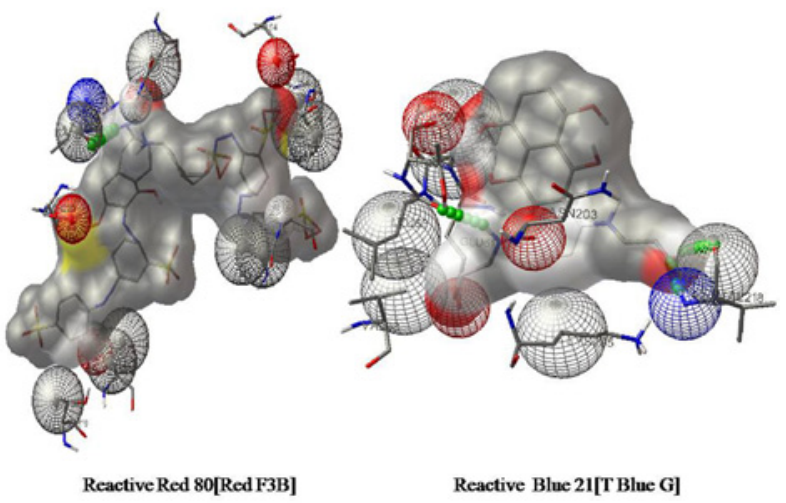

Figure 5: Molecular docking shows the interaction between dye and laccase.

chemistry qualities of the structures were validated with PROCHECK [37] structural validation tool. PROCHECK results clearly indicated the higher fidelity of modeled Laccase structure Figure 4.

\section{Molecular docking studies}

The enzyme Laccase and dyes Reactive Red 80 and reactive Blue 21 were subject to molecular docking analysis using AutoDock Module, which is available in PYRX-0.8 software. In the AutoDock Module, molecular docking was performed using Genetic algorithm parameters with a maximum of 25, 00, 000 energy evaluations Table 4 . Later, results were analyzed with the help of AutoDock [38] tools 1.4.5. The interactions between the ligand and the target are given in Figure 5. The amino acids interact with dyes are exhibiting remarkably enhanced binding affinities. The residue Valine 218 was interacting with two dyes and plays a potential role in degradation. The higher affinity of this small molecule was presumably attributed to the formation of hydrogen bonds and eventually leads to the degradation of dyes. The hydrogen bond between drugs and Laccase are highlighted as green colour beads Figure 5 .

\section{Conclusion}

The utilization of bioremediation techniques in the degradation of industrial pollutants is a research field of high focus. Particularly, laccase enzymes play a vital role in biodegradation of toxic substances. From this study, it is evident that immobilization of laccase enzyme using calcium metal ion would enhance its activity when compared to zinc metal ion. Also, the optimum $\mathrm{pH}$ for a maximum laccase enzyme activity in dye degradation is 5.5. The interaction between the dyes and enzyme were discussed effectively with the help of in silico analysis. Hence, employing immobilized laccase enzyme for the degradation of dyes Reactive Red 80 and reactive Blue 21 could be effective bioremediation method to prevent industrial pollution.

\section{Acknowledgement}

Cordially, we would like to thank our director Dr.P.Arumugam, ARMATSBIOTEK and all my colleagues for their moral support in this study.

\section{References}

1. Revankar MS, Lele SS (2007) Synthetic dye decolorization by white rot fungus, Ganoderma sp WR-1. Biores. Technol 98: 775-780.

2. Forgacs E, Serháti TC, Oros G (2004) Removal of synthetic dyes from wastewaters: a review. Environ Intern 30: 953-971.

3. Behnajady MA, Modirshahla N, Fathi H (2006) Kinetics of decolorization of an azo dye in UV alone and UV/H2O2 processes. J Haz.Mat 136: 816-821.
4. Van der Zee FP, Villa Verde S (2005) Combined anaerobic-aerobic treatment of azo dyes- A short review of reactor studies. Water Res 39: 1425-1440.

5. Baldrian P, Snajdr J (2006) Production of ligninolytic enzymes by litter-decomposing fungi and their ability to decolorize synthetic dyes. Enzyme Microbiol Technol 39: 1023-1029.

6. Durán N, (1997) The impact of biotechnology in the pulp and paper industry(Eds.), Progress in Microbial Ecology.

7. Gianfreda LF, Xu JM, Bollag (1999) Laccases: a useful group of oxidoreductive enzymes. Bioremediation J 3:1-26.

8. Raimbault M (1998) General and microbiological aspects of solid substrate fermentation. J Biotechnol 1:174-188.

9. Couto SR, Sanromán MA(2005) Application of solidstate fermentation to ligninolytic enzyme production. Biochem Eng J 22: 211-219.

10. Gao JM, Weng HB, Zhu DH, Yuan MX, Guan FX et al.(2008) Production and characterization of cellulolytic enzymes from the thermoacidophilic fungal Aspergillus terreus M11 under solid-state cultivation of corn stover. Bioresource Technol 99: 7623-7629.

11. Bollag J.M , Leonowicz A (1984) Comparative studies of extracellular fungal laccases. Applied and Environmental Microbiology 48: 849-854.

12. Munoz C, Guillen F, Martinez AT, Martinez MJ (1997) Induction and characterization of laccase in the lininolytic fungus Pleurotus eryngii. Current Microbiology $34: 1-5$.

13. Taniguchi H, Hosoda A, Tsuno T, Maruta Y, Nomura E (1999) Preparation of ferulic acid and its application for the synthesis of cancer chemopreventive agents. Anticancer Research 19: 3757-3761.

14. Revankar MS, Lele SS (2006) Enhanced production of laccase using a new isolate of white rot fungus WR-1. Process Biochem 41:581-588.

15. Durán N , Esposito E (1997) Lignin biodegradation and effluent treatment by ligninolytic fungi, in: Microbiologia Ambiental 12: 269

16. Edwards W, Bownes R, Leukes WD, Jacobs EP, Sanderson R, et al. (1999) Capillary membrane bioreactor using immobilized polyphenol oxidase for the removal of phenols from industrial effluents. Enzyme Microb Technol 24: 209 217

17. Sisak C, Nagy E, Burfeind J, Schugerl K (2000) Technical aspects of separation and simultaneously enzymatic reaction in multiphase enzyme membrane reactors. Bioprocess Eng 23: 503-512.

18. Karam J, Nicell JA (1997) Potential application of enzymes in waste treatment. J Chem Technol Biotechnol 69:141.

19. Duran N, Esposito E (2000) Potential applications of oxidative enzymes and phenoloxidase-like compounds in wastewater and soil treatment: a review. App Catal B: Environ 28:83-99.

20. Peralta-Zamorav P, Pereira CM, Tibursio EL, Moraes SG, Minussi RC,et al.(2003) Decolorization of reactive dyes by immobilized laccase. Applied Catalysis B: Environmental 42: 131-144.

21. Cordi L, Freire RS, Kubota LT, Duran N (2000) Laccase immobilization on pyrolytic carbon in Kraft E1 effluent treatment. Proceedings of the Seventh National Meeting on Environmental Microbiology.

22. Freire RS, Durán N , Kubota LT (2001) Effect of fungal laccase immobilization procedures for the development of a biosensor for phenol compounds. Talanta 54: 681-686.

23. Benny Cheefetz, Yona Chen, Yitzhak Hadar (1998) Purification and Characterization of Laccase from Chaetomium thermophilium and Its Role in Humification. Applied and environmental biology 64: 3175-3179.

24. Anna jarosz-wilkolazka, Janina Kochmanska-Rdest, Elzbieta malarczyk, Wladyslaw Wardas (2002) Fungi and their ability to decolourize azo and anthraquinonic dyes. Enzyme and microbial technology 30: 566-572

25. The Universal Protein Resource (UniProt) (2009) UniProt Consortium, Nucleic Acids Res. 37

26. Altschul SF, Gish W, Miller W, Myers EW, Lipman DJ (1990) Basic local alignment search tool. J Mol Biol $215: 403-410$.

27. Berman HM, John Westbrook, Zukang Feng, Gary Gilliland, TN Bhat, et al (2000) The Protein Data Bank, Nucleic Acids Res 28: 235-242. 
Citation: Velu C, Veeramani E, Suntharam S, Kalimuthu K (2011) Insilico Screening and Comparative Study on the Effectiveness of Textile Dye Decolourization by Crude Laccase Immobilised Alginate Encapsulated Beads from Pleurotus Ostreatus. J Bioprocess Biotechniq 1:109 doi: 10.4172/2155-9821.1000109

Page 6 of 6

28. Thompson JD, Higgins DG, Gibson TJ (1994) CLUSTAL W: improving the sensitivity of progressive multiple sequence alignment through sequence weighting, position-specific gap penalties and weight matrix choice. Nucleic acids research 22: 4673-80.

29. Eswar M, Marti-Renom MA, Webb B, Madhusudhan MS, Eramian D, et al. (2006) Comparative Protein Structure Modeling With MODELLER.Current Protocols in Bioinformatics 15: 5.6.1-5.6.30.

30. Eramian D, Shen MY, Devos D, Melo F, Sali A ,et al. (2006) A composite score for predicting errors in protein structure models. Protein Science 15: 16531666.

31. Pettersen EF, Goddard TD, Huang CC, Couch GS, Greenblatt DM,et al. (2004) UCSF Chimera visualization system for exploratory research and analysis. $J$ Comput Chem 25: 1605-1612.

32. William H, Andrew D, Klaus S (1996) VMD - Visual Molecular Dynamics. Journal of Molecular Graphics 14: 33-38

33. Trott O , Olson AJ (2010) AutoDock Vina: improving the speed and accuracy of docking with a new scoring function, efficient optimization and multithreading Journal of Computational Chemistry 31: 455-461.

34. Fedoryuk MV (2001) Method of steepest descent in Hazewinkel, Michiel, Encyclopaedia of Mathematics. Springer.

35. Halgren T.A (1996) Merck Molecular Force Field. V. Extension of MMFF94 using experimental data, additional computational data and empirical rules. $J$ Comp Chem 17: 616-641.

36. Hegde S, Kavitha S, Varadaraj MC, Muralikrishna G (2006) Degradation of cereal bran polysaccharide-phenolic acid complexes by Aspergillus niger CFR1105. Food Chem 96: 14-9.

37. Laskowski RA, Rullmannn JA, MacArthur MW, Kaptein R, Thornton JM (1996) AQUA and PROCHECK-NMR: programs for checking the quality of protein structures solved by NMR, J Biomol NMR 8: 477-486.

38. Morris GM, Goodsell DS, Halliday RS, Huey R, Hart WE, et al. (1998) Automated Docking Using a Lamarckian Genetic Algorithm and and Empirical Binding Free Energy Function. J Computational Chemistry 19: 1639-1662. 